\title{
Transnational formations of race before and during Yugoslav state socialism
}

In domains from the history of popular entertainment to that of ethnicity and migration, ideas of race, as well as ethnicity and religion, have demonstrably formed part of how people from the Yugoslav region have understood their place in Europe and the world. The region's history during, and after, the era of direct European colonialism differed from the USA's, France's or Brazil's; but this did not exclude it from the networks of 'race in translation' (Stam and Shohat 2012) which ran and run across the whole globe, not just around the postcolonial Atlantic. Among the political, social and cultural 'legacies' that the Bulgarian historian Maria Todorova (2005a: 69) argues give regions like the Balkans their intellectual coherence are, therefore, formations of racialised difference in areas to which the Yugoslav region has historical connections - even though Todorova's own work on Balkan history is ambivalent about the utility of race.

Perceptions that south-east Europe is distinct enough to be 'a region' arise, for Todorova, when historical experiences associated with specific regimes (and their collapse) intersect with constructions of territory. 'The Balkans', one such region-as-legacy, depends on the idea that the legacy of Ottoman rule in Europe still explains something about it; 'Eastern Europe' often stands for the perceived legacy of the collapse of multi-national long-nineteenth-century but was really, Todorova suggested, based on perceptions of the legacy of state socialism (2005a: 69-73). These perceptions themselves have often, wrongly, been bases for treating eastern Europe as inherently lagging behind the West - and yet it is precisely the history of fin-de-siècle European scientific racism, 
she hints briefly in a reading of the racialised hatred of Albanians that Vladan Đorđević expressed in 1913 (see Chapter 2), that should place south-east Europe in a common European or global space and in the proper comparative perspective', not 'ghettoiz[ed] ... in a diachronic and spatial Balkans continuity' (Todorova 2005b: 156-7). ${ }^{1}$

The emphasis on plural formations and imaginaries, rather than one globalised homogenous regime of thought, in theories of global raciality opens further possibilities for understanding 'race' in peripheralised regions like south-east Europe. Another Bulgarian scholar, Miglena Todorova, has demonstrated how scientists, politicians, cultural producers and the public in Bulgaria adapted not one but many foreign discourses on race to Bulgarian social realities: with northern European biological and scientific racism; the cultural racism that had manifested alongside it by the 1930s; US racialised imaginaries of African primitivity then, later, African-American physicality, musicality and criminality; and Soviet imaginaries of state socialist Europe at the vanguard of a new humanitarian civilising mission to develop and modernise postcolonial Africa all contributing (Todorova 2006). Equivalent sources for the Yugoslav region's translations of 'race' would be similar but - because of its pre-unification history as well as the geopolitics of socialist NonAlignment - not the same.

Yugoslavia's participation in the Non-Aligned Movement (NAM) has very recently come into view in scholarship 'between the posts' (Chari and Verdery 2009) of postsocialism and postcolonialism as an explanation for its ambiguities within global raciality. The autonomous foreign policy and Marxist ideology that Yugoslav Communists sought after the 1948 Tito-Stalin split led Yugoslavia to become a founder member of this self-declared geopolitical third force that emerged from the 1955 Bandung conference of anti-imperialist African and Asian states. Recovering Non-Alignment as a topic of Yugoslav history creates muchneeded space to recognise race in the region. Yet, even before Yugoslav unification, the region already occupied a distinctive conjunction of racial formations, with Venetian and Habsburg rule positioning different parts in Italian-speaking and German-speaking cultural areas; though 
South Slav national movements viewed both Italians and Germans as dominators, they still translated Italian and German identity discourses on to themselves. Italian and German imaginaries of race have rarely been related to the Yugoslav region beyond the debate in Second World War historiography about how far Fascism and Nazism influenced the NDH (Kallis 2015); they still laid foundations that would transform again as the Yugoslav region negotiated the geopolitics of the Cold War.

\section{Venetian formations of race}

In October 2015, the Croatian football club HNK Rijeka, nicknamed 'Bijeli' ('Whites') for their all-white home strip, wore an unusual fourth kit against nearby Opatija: a purple shirt half-covered by a black-skinned, turbaned head, with prominent red lips and gold-rimmed eyes. ${ }^{2}$ Rijeka's sporting director, hailing the team as 'world-class' for being the first Croatian club with a fourth kit, hoped that 'Rijeka is a touristic city and these strips ... could comfortably stand as tourist souvenirs' (Benčić 2015b). Rijekans, Opatijans, and Croatians more widely would have recognised the figure as the 'morčić' ('little Moor'), a traditional Rijeka carnival character wearing blackface and an ornate costume evoking Ottoman elite dress which decorates earrings, necklaces and tourist souvenirs. Viewed through transnational histories of race, however, its appearance, carnival associations and supposed Moorish origin resonate uncomfortably with 'Zwarte Piet', the black-faced servant in Dutch Christmas traditions, whom Dutch people of colour and anti-racists have been protesting against since the 1960s (see Wekker 2016: 139-67). The morčić attracts no comparable protests, either during carnival or in Rijeka's tourist promotion. It is mostly viewed as a quirky, unproblematic memento of the Venetian Adriatic (when Venice ruled much of the Istrian and Dalmatian coast, though not Rijeka). Yet Venetian racial imaginaries, constructed against Venice's Ottoman rivals and 'the Moor', may even have been the first racialising discourses 'translated' into at least this part of the Yugoslav region - leaving the morčić and Zwarte Piet not so far apart. 
Venetian racialisation of Turks as black, with 'stereotypical black African physiognomies' in painting and sculpture, dates to the late fifteenth century and peaked during the Venetian-Ottoman wars (Kaplan 2011: 41). The trope, which inspired Shakespeare's Othello (leading to much more literature about this representation of race in early modern Venice than the history of race in early modern Venice itself), probably originated from existing traditions of painting Muslims and Egyptians as black Africans (Kaplan 2011: 47-9). Though Rijeka was Habsburg (Hungarian Croatia's main port) not Venetian, Italianate heritage is part of its contemporary identity. Other Moorish characters and blackface customs appear in Dalmatian/Croatian folk traditions further south, including Dubrovnik/Ragusa (independent until annexed by Napoleon in 1808) and the islands of Korčula (Venetian 1420-1797) and Lastovo (Ragusan until 1808).

Dubrovnik and Korčula folk traditions both include the 'moreška', a sword-dance where two kings fight over a symbolic princess, which ethnologists have compared to Spanish 'moros y cristianos' ('Moors and Christians') customs, Venetian mock factional battles and English morris dancing. Its contest between a Black King, who has abducted the princess and whose dancers traditionally (though rarely today) wear black faces or masks, and a White King, who in Korčula has the Turkish name Osman, has been interpreted as Christians against Moors and also as Moors against Turks. ${ }^{3}$ One reading of the Korčula moreška, which emerged under Venetian rule, finds both a public narrative of Christian-Muslim combat and a resistive 'hidden transcript', accessible to Korčulans but not their rulers, where the Black side could be Korčulans, the Whites Venice and the princess the violated land (Harris and Feldman 2003: 312). ${ }^{4}$ Lastovo's carnival meanwhile centres around making and burning a brown-faced effigy, wearing a fez and moustache, called 'the Turk'; traditionally, this simultaneously represents one of a band of Catalan pirates who unsuccessfully attacked Lastovo in 1483 or 1571 and the culprit for every misfortune suffered there since the previous spring (Oroz 2009).

What, however, do the morčić or Turk, or vestiges of whiteness and

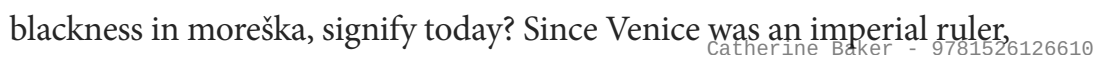


with its eighteenth-century travel writer Alberto Fortis exoticising Dalmatian highland Slavs and Vlachs into the orientalised, at least partially racialised 'Morlachs' (Woolf 2002), the direction of power is different from the Netherlands, where white Dutch people were the colonisers and enslavers of the black Africans stereotyped by Zwarte Piet. Yet just because eastern Adriatic national and regional identities developed in reaction against Venetian rule and Italian irredentism does not mean they formed in isolation from Venetian and Italian imaginaries of race (Ballinger 2004). Indeed, when the Dalmatian writer Giovanni Lovrich wrote back against Fortis to argue that the Morlachs could still be enlightened once lifted out of Turkish rule, he did so by refuting Fortis's rumour that Morlach women had the Hottentots' pendulous breasts (Bracewell 2011) - meaning Lovrich's reader still had to share the racialised stereotype of Hottentot women (a key trope in Europeans' construction of 'Europeanness' against racialised and sexualised imaginaries of African bodies) to understand what Lovrich was distancing the Morlachs from. ${ }^{5}$ Moreover, when anthropologists hold that folk/carnival customs re-narrate the present around traditional symbols rather than simply re-enacting historical events, one can and should accept that contemporary racial formations will be among these traditions' undertones of meaning now even if they were not before. Yet the morčić and the Lastovo Turk do not elicit protest like Zwarte Piet, and anti-racist activism in Rijeka has other pressing priorities (fighting antiziganism and anti-Serb chauvinism, and migrant solidarity). Whether future Croatian social movements will frame carnival traditions as anti-blackness remains to be seen.

\section{Race in the German-speaking cultural area and the Habsburg Empire}

If Venetian imaginaries of race are part of the Yugoslav region's 'translation' even though Venetian rule there ended during the Napoleonic Wars, even more significant would be those from a cultural space to 
which the north and west of the region were connected for centuries as Habsburg peripheries: the German linguistic-cultural area, which overspilled from Germany - the most-researched country after Britain and France in Black European Studies (see Gilman 1982; Campt 2004) - into the Habsburg Empire. German-language literary, visual and consumer culture was part of the Habsburg South Slav everyday, as Pamela Ballinger (2004: 35) and Maria Todorova (2005b: 157) both hint when suggesting the aesthetics of whiteness, blackness and raceas-blood in Germany described by Uli Linke (1999) might have been disseminated to their regions of interest. Just as scholars trace the production of whiteness through 'cultural archive[s]' (Wekker 2016: 2) of advertising material, travel literature, schoolbook representations and visual ephemera for fin-de-siècle northern European countries (Zantop 1997; Loftsdóttir and Jensen (eds) 2012b; Wekker 2016), formations of race would become explicit if scholars of the ex-Habsburg lands did the same.

Late Habsburg cultural history has surprisingly rarely addressed race and anti-blackness in consumer and leisure culture, far less across the wider empire outside metropolitan, majority- German-speaking Vienna. Transnational studies also pass over it. In 1989-90, Amsterdam Tropical Museum's 'Negrophilia' exhibition - the basis of Jan Nederveen Pieterse's study of images of Africa and blackness in Western popular culture (Pieterse 1992: 15) - collected US, British, German, French and Dutch representations, with its transatlantic and transnational scope hailed as innovative (Pieterse 1992: 15), yet its 'Europe' went no further east than Imperial Germany (and no further south than the Pyrenees). Coloniality and race, in this end-of-the-Cold-War exhibition, was not a lens applicable to eastern Europe, conceptually the 'Second World' for forty years. Two decades later, a Louvre exhibition on 'human zoos' (which used to draw European spectators into an imperial gaze in person by beholding people of colour in exoticised tableaus) traced them 'through western Europe' into the USA and Japan (Blanchard, Boëtsch and Snoep 2011: 28). Yet, besides one brief reference to 'travelling village[s]' being exported to 'other northern and eastern European countries, though ... less visible' 
in the latter (Lemaire et al. 2011: 292), and counting Vienna among the zoos that hosted them (Schneider 2011: 131), these transnational studies rarely synthesise as far as eastern Europe - despite evidence that they should (Novikova 2013).

Yet 'commodity racism' (McClintock 1994: 130), the mass production of racialised narratives/visualisations of modernity and primitivism around commodities extracted from colonised land, permeated as a transnational, implicitly 'European' mode of representation far beyond the largest metropoles into smaller northern European countries like Switzerland and Iceland (Loftsdóttir 2010; Purtschert and Fischer-Tiné (eds) 2015). Inner Austria, indeed, is already within the scope of studies of German advertising, race and empire, since Austrian firms manufactured and designed for both German and Habsburg markets within a cross-border consumer culture (Ciarlo 2011: 9-11). Austria and Hungary were both nodes in the 'human zoo' tradition that emanated across Europe from Germany, and Vienna and Budapest regularly hosted touring anthropological spectacles in the 1890s-1900s, including exhibits of Australian Aborigines, Buffalo Bill's Wild West show (with dozens of Native Americans) and an Ashanti village, plus shows by the leading human-zoo entrepreneur, Carl Hagenbeck (Scott 1997; Hund 2013: 46; Rydell 2013: 97).

Marilyn Scott (1997: 51) suggests that, in increasingly multi-ethnic industrialising Vienna, this European colonial imagination offered a route for 'assimilation' across ethno-linguistic boundaries, where Europeanness and whiteness gave the multi-ethnic Habsburg imperial identity extra connective tissue. Indeed, invitations to participate in this gaze extended beyond the Habsburg capitals. Touring 'Dahomean' and 'Ashanti' villages came twice to Prague in the 1890s, just when the 1885 Berlin Conference, the 1889-94 Franco-Dahomean Wars and the 1895-6 British occupation of the Ashanti Empire were making these very territories' and peoples' colonisation a European geopolitical fascination (Herza 2016: 97). What impressions did the travelling villages leave in Zagreb, or other soon-to-be-Yugoslav cities? Zagreb did not have its own zoo until 1925, after unification, and more research is 
needed on what exhibitions might have passed through other sites; yet illustrated media reports and postcards from other cities' exhibitions (see Deroo and Fournié 2011) would nevertheless have disseminated these anthropological aesthetics further into Habsburg visual culture, including to Zagreb.

Nostalgic notions of 'peaceful and unambitious' (Bach 2016: 22) Habsburg imperialism, outside the European colonial mainstream, fall down against evidence of how nineteenth-century Habsburg officials and writers imagined a civilising mission in south-east Europe comparable to other powers in Africa and Asia (Fuchs 2011), and of Habsburg entanglements in colonialism overseas (Sauer 2012). Habsburg authorities in Bosnia-Herzegovina, for instance, tackled what they perceived as an Ottoman legacy of endemic backwardness through extensive public health programmes. The Czech-, Russian- and Polish-speaking, Swisstrained women physicians they hired to visit Muslim women in 'the harems' (as per one 1903 public health report) took British women doctors' work in the gender-segregated Indian 'zenana' as a model, making Bosnia-Herzegovina 'the object of a characteristically colonial discourse' (Fuchs 2011: 76, 85; see Burton 1996). Habsburg distinctions between 'historic' peoples (Germans, Magyars, Italians) and peoples without history (Slavs, Romanians) (Glajar 2001: 19) juxtaposed the same temporalities with which Europeans divided places and peoples into civilised and backward zones (Mignolo 2000). Viewing European colonial dominance beyond just the direct colonisation of territory overseas meanwhile reveals multiple dimensions of Austro-Hungarian implication in global coloniality: from the travels of expatriate missionaries, doctors, agents and freelance 'explorers' (Chapter 2), to short-lived Indian Ocean fortresses supporting the empire's eighteenthcentury trade, several failed plans to colonise the Nicobar or Solomon Islands in the nineteenth century, or the 1873 North Pole expedition (Sauer 2012). Since the Yugoslav region obtained many of its racial imaginaries from the empires that ruled it, studies of racial thought at the Habsburg imperial centre (e.g. Sluga 2001; Ruthner 2002; Turda 2014) are also part of the context for historicising 'race' there. 
The afterlife of German imaginations of indigeneity, still meaningful in late-twentieth-century Yugoslavia, shows how everyday Germanlanguage racialised imaginaries in the region could remain. German fascination with Native Americans, ignited by Karl May's Winnetou novels (1875-1910), inspired hobbyist re-enactment groups and many popular films, and arguably represented a certain racial exceptionalism itself (May's white German protagonist, allied with Natives against villainous Americans, embodied a brotherhood with the Indian hero that distanced the nation from its own colonialism) (Sieg 2002). This fascination was directly accessible in Yugoslav popular culture, with May's books translated and well known. The Croatian musician Alka Vuica, for instance, said she started writing verse 'aged around 12, when I fell in love with Winnetou after reading Karl May's trilogy' (Car 2015), and named her debut album Alka Vu Winnetou in 1993; another Istrian musician, Franci Blašković, formed a band called Gori Ussi Winnetou in 1986. Through film production, moreover, German fascination with Native Americans simultaneously incorporated Yugoslavia into the material and financial circuits of a transnationally produced and disseminated imaginary.

Both West Germany's ten Winnetou films (1962-8) and the East German 'Indianerfilme' (1966-77) - with very different ideological frames around settler-Native relations - were filmed in Yugoslavia, making the Dalmatian hinterland's dusty valleys the backdrop for both Germanies' imagined Wild Wests (Goral 2014: 8). Local extras and stuntmen played most Native characters (Goral 2014: 84). Jadran Film, one of Yugoslavia's largest studios, co-produced the Winnetou cycle, while a Yugoslav actor, Gojko Mitić, became arguably East Germany's first film star as the lead in Indianerfilme (Goral 2014: 1, 67). Mitić remained in East German film and television, and in 1991, postreunification, started performing live as Winnetou himself at the annual Winnetou festival held since 1952 in Schleswig-Holstein. Katrin Sieg (2002: 105) suggests casting the olive-skinned, well-built Mitić epitomised the 'exotic virility' and 'racial fetishism' gradually attached to Winnetou - another example of the ambiguous racialised identifications often available to south-east European entertainers. 
The subject positions that these cultural translations of 'the Wild West' offered East German or Yugoslav spectators, conversely, distanced both nations from the whiteness of settler colonialism. The official historical narrative in Indianerfilme, reflected in one of Mitićs interviews while making the first (Die Sohne der grossen Bärin (Sons of the Great She-Bear), $1966^{6}$ ) was of a USA founded on racialised theft and conquest, as Mitić stated in his interview: 'The white people invaded the land of the Indians and wanted to take away their habitat because they wanted to live here too ... basically, the whites ended up taking over the country' (Goral 2014: 91). State socialist subjects, taking up identification with Natives not settlers, implicitly belonged to a different geopolitical tradition. In late socialist Yugoslavia, the Western's tropes arguably underwent even more 're-appropriation' (Jelača 2014: 250): in Dijana Jelača’s reading of a 1985 song by the rock band Haustor about the famous character Shane, his 'normative, silent, White Western outcast masculinity' became 'a fantasy echo of escape from one's own cultural and societal confinement', rejecting rather than reiterating hegemonic ideology. This fantasy about escaping the cultural stagnation of late socialism might become, in the 1990s, a fantasy of escaping the violent imposition of ethnicised borders in which listening to a pre-war band singing about the dream of identification with Shane would not have been an identification with masculinist militarised nationalism but an escape from it (Jelača 2014: 254). Even within the expanding history of state socialism and race, the impact of the 1990s wars on memory and identity set the Yugoslav region apart; yet the geopolitics of Non-Alignment had already distinguished Yugoslavia during the Cold War.

\section{State socialism, postcoloniality and 'connected histories' of the USSR and eastern Europe}

Historians already acknowledge the Cold War politics of envisioning state socialist space as a moral identity opposed to imperialism and capitalism, versus a USA built on racialised oppression, as a geopolitics of race. US policymakers partially realised, and Soviet diplomats exploited, 
the contradictions of advocating 'freedom' internationally while the Civil Rights and Black Power movements showed African-Americans were still far from free (Dudziak 2000; Borstelmann 2001). Keen to persuade foreign observers that the USA originated from a history of colonialism and white supremacy, the USSR offered African-Americans a performative welcome, and under Lenin had declared an intention to unite the world's racialised peoples against imperialism (Baldwin 2002; Roman 2012). After 1945, competing with the USA for influence in decolonised Africa, Khrushchev targeted the 'Third World' with cultural diplomacy, propaganda and student exchanges, and later Soviet leaders equipped and trained southern African armed liberation movements (Westad 2005; Matusevich (ed.) 2007; Bradley 2010). US and Soviet geopolitics of race evolved in interaction, in mainstream diplomacy and even the gendered structures of feeling and domesticity through which both powers constituted themselves against each other (Baldwin 2016). Permanent, as opposed to temporary, black and African presence was nevertheless erased in a Soviet racial politics that 'productively link[ed] Russianness to whiteness' (Fikes and Lemon 2002: 517) abroad.

Soviet racial formations influenced, but did not fully overwrite, constructions of race, whiteness and modernity in state socialist eastern Europe: adaptation to Soviet ideology was less an exercise in unthinking conformity, more an uneasy balance between responding to domestic factors and averting the coercion awaiting (as Hungary 1956 and Czechoslovakia 1968 reminded Communists elsewhere) a Party deviating too far from Soviet objectives. Without eastern Europe having any acknowledged history of implication in European colonialism, exceptionalism compounded by the whiteness of the Western academy has made race appear of little relevance for understanding this area. As recent studies of the Cold War trace material, political and intellectual links between the so-called 'Second' and 'Third Worlds' in order to unmake the conceptual borders that generally separate the histories of state socialism and decolonisation, however, they lay foundations that make questions about 'race' and whiteness in state socialist Europe both easier and more necessary to conceive. 
Within the entangled histories of state socialism and decolonisation, east European states as well as the USSR offered development assistance to newly independent African and Asian countries, hosted foreign students, organised public anti-colonial solidarity campaigns, and participated in bilateral and multilateral internationalism. Race, in these activities, was discursively invisible behind state socialist rhetoric of internationalism and class. Quinn Slobodian, introducing a volume on East German engagements with the Global South, poses questions one could ask across the region:

What was the status of race in a socialist world view that deemed class to be the medium that dissolved all other differences? How did race and racialized thinking operate in a socialist society like East Germany that had decreed racism out of existence? What alliances were created across ethnic lines in the German project of state socialism that had not, and could not, have existed before? (Slobodian 2015a: 1)

East German topics have taken the lead in studies of race and state socialism because Afro-German scholarship and activism and the social politics of post-unification racism and anti-racism after 1989 have made race a (relatively) more important theme in German Studies than east European studies; moreover, politics of academic knowledge production privileging larger countries at the Western 'centre' make studies of Germany relatively more likely to be published. Slobodian's Comrades of Color came shortly after monographs on Mozambican students educated in East Germany (Müller 2014) and East and West German humanitarianism towards the Third World (Hong 2015). All combined microhistories of people of colour moving temporarily or permanently to state socialist countries with analysis of constructions of race that - however race-blind state socialist rhetoric and the international discourses of cultural diversity that had been shaped through UNESCO both were (Shilliam 2013: 153; Subotić and Vučetić, forthcoming) had still been formed through white east Europeans' engagements with and travel to postcolonial states. Indeed, Miglena Todorova on twentieth-century Bulgaria anticipated much of the transnational 
turn in Cold War history by centring race as part of identity under state socialism.

'European' scientific ideas of race as biology, 'American' sociological ideas of race as culture and Soviet racial thought were all being adapted by thinkers who positioned themselves within the Bulgarian ethnonation to explain and racialise socio-economic conditions, especially Romani poverty, even before 1945. State socialism did not make race disappear. Bulgarian Communism used categories of nationality not race, and applied an enlightened, race-blind internationalism to geopolitics, yet still possessed a racialised ideology (Todorova 2006: 216-17). Antiziganism persisted, though expressed in ostensibly anti-racist terms; discourses about Communist successes in modernising Africa had 'civilising mission' overtones; and teaching materials including biology textbooks still provided 'common-sense' knowledge about biologically defined race.

Todorova argues, similarly to Gloria Wekker (2016) that 'Bulgarian students learned ... their own whiteness' through these textbooks, which showed white Europeanoid, yellow Mongoloid and black Negroid races while clearly distancing the latter two from Bulgaria (Todorova 2006: 198-9). In the mid-1980s, when a relaxation in cultural policy made more US film, television and popular music available, white Bulgarians viewed African-Americans through what they already knew about Roma, tightening the ascribed identification between the two groups (Todorova 2006: 292-4). Marxism-Leninism and liberalism, though opposites in the Cold War ideological-spatial binary, ultimately appeared to agree on race: both belonged to 'a modern epistemological world defined by whiteness and Eurocentric culture' and both envisaged futures where particularist racial, cultural and religious identities would be subsumed into a universalist society that could reform the globe (Todorova 2006: 176). This synthesis of critical race scholarship and south-east European social theory resonates beyond Bulgaria. Valuable throughout the Yugoslav region's history, it helps above all to unpick the complexities of foreign policy, internationalism and race within Yugoslavia's geopolitical identification with the Non-Aligned Movement 
of states defining themselves as developing and postcolonial, part of distinguishing Yugoslav from Soviet Communism.

\section{Yugoslavia, the NAM and race}

The NAM, positioned between US capitalism and Soviet state socialism, has for that very reason often been Eurocentrically discounted in Cold War historiography as irrelevant to the grand narrative of superpower relations. In the history of decolonisation, however, it represents the next stage of the Afro-Asian and anti-colonial Bandung conference movement, which gathered thirty mostly African and Asian states at the first Asia-Africa Conference in 1955. ${ }^{7}$ Their grouping exemplified the post-war 'racial break' (Winant 2001: 143), framed by Gilroy (2000: 273 ) as a 'post-Bandung' planetary racial politics. Tito cultivated links with powerful Bandung leaders, including Ethiopia's Haile Selassie whose 1954 visit to Yugoslavia anticipated Tito's later spectacles of Non-Alignment (Orlović 2012) - India’s Jawaharlal Nehru and the post-Suez Egyptian president Gamal Abdel Nasser. Tito's meeting with Nehru and Nasser in July 1956 on Brioni, where Tito famously invited leaders and celebrities from both superpower blocs and beyond, laid groundwork for the first Non-Aligned conference in Belgrade in $1961 .^{8}$

Yugoslavia, usually considered a NAM founding member alongside Egypt, Ghana, India and Indonesia, was a greater ambiguity or outlier in the movement's anti-colonial orientation and Afro-Asian-centred geopolitics than any participant at Bandung. Bandung's only European participants were Cyprus and (simultaneously in Europe and Asia if the Bosphorus represents their border) Turkey. Neither ascribed itself the role that Tito would write into Yugoslavia's official ideological and geopolitical identity. Yugoslavia was a European power in a region (the Balkans) perceived in Western discourses of modernity as European and not-European simultaneously; on territory formerly subject to one empire centred in central Europe and another centred in west Asia; where members of majority ethnonational groups (including their 
diasporas) were usually racialised as white but whose whiteness had still been conditional or 'white, but not quite' (Alcoff 1998: 9) to northern European and North American gazes in living memory; ${ }^{9}$ and where ethnonational identities already, before and after unification in 1918 (and Communist-led reunification in 1943-5) incorporated adaptations of racial thought.

Yugoslavia's geopolitical non-alignment was a global restatement of the ideological belonging and distancing that Yugoslav Communism had been performing since the early 1950s, after the 1948 Tito-Stalin split (Mišković, Fischer-Tiné and Boskovska (eds) 2014; Životić and Čavoski 2016). Distinctive elements of Yugoslav Communism included a socio-economic ideology of 'workers' self-management' (experimentally extended into politics by 1974); aspirations to produce more consumer goods and offer higher living standards than Soviet-style planned economies could provide; a cultural policy which was (uneasily) more open than Warsaw Pact regimes to capitalist countries' artefacts and aesthetics; and a foreign policy that played both blocs against each other in trade yet feared invasion by either superpower, not just one. Within Europe, Tito's Yugoslavia has often been described as demonstratively standing 'between East and West', outside the Cold War binary (Kulić 2009). Decentring this binary, an aim of global Cold War history and indeed NAM, requires treating the East-West axis as only one of the historical-geopolitical hierarchies in play during the Cold War.

Common descriptions of Tito as one of the NAM 'founding fathers' (Adebajo 2016: 1192) alongside Nehru and Nasser not only suggest how power and leadership were gendered masculine in NAM diplomacy but also call for answers about how Yugoslavs reconciled attachments to Europeanness and whiteness with the logic of NAM (Kilibarda 2010). Yugoslavia's geopolitical realignment began with bilateral relations with India, expressed through the first joint Nehru-Tito statement in December 1954. This stated both countries had 'emerged as independent nations, through powerful movements of national liberation', with strong 'similarities of historic background and social and economic conditions' (Mišković 2009: 186). Yugoslavia’s role in NAM implied its closest 
geopolitical counterparts were outside Europe but facing shared challenges of modernisation after liberation from imperial rule. Indeed, the United Nations Conference on Trade and Development - where Yugoslavia was heavily involved - assigned Yugoslavia to Group A (African/Asian states) rather than Group D (eastern Europe), or for that matter B or $\mathrm{C}$ (developed market economies and Latin American/Caribbean states respectively) (Alden, Morphet and Vieira 2010: 53-4). ${ }^{10}$

Non-Alignment made Yugoslavia’s geopolitical and racialised identities even more ambiguous than the Soviet bloc's. Was Yugoslavia positioning itself outside Europe, or outside the coloniality with which postcolonial thought and critical race theory make Europe synonymous? Where did its ideology position South Slavs within (or outside) whiteness and 'race' - or was the UNESCO era's very race-blindness a precondition for predominantly-yet-contingently-white Yugoslavia to even be able to enter this self-declared subaltern coalition, and to claim parity with territories robbed of resources, wealth and people by white Europeans? Mao maintained Yugoslavia could do neither of those things, and spoke for Afro-Asianism not the expanded NAM (Byrne 2015: 921); yet many African leaders welcomed Tito. Besides a diplomatic grouping, the NAM was also, at least theoretically, a 'structure of feeling' connecting people with a space larger than the nation (or the alliance of nations Yugoslavia was supposed to be) (Gupta 1992: 64). How, then, did Yugoslavs experience Non-Alignment in practice, and did their state and leader's participation in the global movement change how they perceived their individual and collective places in the world?

Aimé Césaire, the Martinican writer and theorist of Négritude, encountered the complexity of Yugoslavia's relationship to Europeanness and coloniality after befriending the Croatian and Yugoslav linguist Petar Guberina when both studied in Paris - then 'a marketplace for the global spread of anticolonialism' (Goebel 2016: 1444) - in 1934. Césaire began 'arguably the foundational text of the Negritude movement' (Stromberg Childers 2016: 76), Cahier d'un retour au pays natal (Notebook of a Return to the Native Land) while visiting Guberina's hometown Šibenik in 1935 - inspired by seeing a small Dalmatian shore, reminiscent of 
his own Martinique, and learning it had the equivalent name Martinska (Kelley 1999: 6). Guberina founded the Institute for African Studies in Zagreb and co-organised, in 1956, the First Congress of Black Writers and Artists in Paris. Writing for Naše teme, the journal of the Croatian SKJ's mass youth organisation, in the early 1960s, he both promoted the study of African languages and critiqued the politics of translation and essentialism that structured whether and how Yugoslavs, Europeans and Americans encountered African art and poetry (Guberina 1961). The Négritude movement he knew so well coexisted in Naše teme with the 'African Personality' thesis of the Ghanaian president Kwame Nkrumah as modes for conceptualising 'African cultures' (Cvjetičanin 1979).

Césaire and Guberina were reunited by the Kenya-born director Lawrence Kiiru, who settled in Zagreb after studying at the Academy of Dramatic Arts, for a 1990 documentary, Martinska-Martinique. ${ }^{11}$ Amid their interlinguistic performances of fraternity, Césaire called both Martinique and Yugoslavia " "handicapped," "underdeveloped," and “colonized”' societies (Jović Humphrey 2014: 1132). Césaire’s suggestion that colonised peoples creating their new societies might look to Soviet models, Anja Jović Humphrey suggests, contained 'awareness that there exist two Europes ... it was not the colonizer's Europe to which Césaire wanted to turn' (Jović Humphrey 2014: 1133). The Césaire-Guberina friendship, and the Afro-Yugoslav amity Guberina nurtured, represented a nexus between two projects of revising Marxism (Kelley 1999: 4; Césaire 2000 [1972]), but also a nexus between Yugoslavness and blackness permitting some Yugoslavs to identify Yugoslavia with Africa. Jović Humphrey goes as far as to suggest that identification between Slavs and black Africans could rest not only on shared histories of being racialised by German philosophers but even on shared histories of enslavement itself (Jović Humphrey 2014: 1140-1). Yet the Yugoslav region was also one from where South Slavs (like the explorers who joined Stanley in the Congo, or the captains bringing slaves to Ulcinj) had departed to participate in colonising Africa and enslaving Africans - contradicting socialist Yugoslavia's self-image. This tension pervaded the everyday geopolitics of Non-Alignment. 


\section{Everyday Non-Alignment and race in socialist Yugoslavia}

Non-Alignment built identification with global anti-colonial struggle into the narrative of Yugoslavia's state identity - and, implicitly, into Yugoslav Communism's spatial-historical narratives about the South Slav nations (as struggling against their own imperialist rulers, including the interwar Yugoslav monarchy, before pooling their self-determination into socialist Yugoslavia). In February 1961, after the assassination of the Congolese prime minister Patrice Lumumba, the SKJ called a rally in Belgrade attended by 150,000 , with a breakaway demonstration of 30,000 occupying the Belgian embassy and clashing with police (Kilibarda 2010: 33; Robertson 2015: 112). Tito, meanwhile, espoused race-blind anti-colonialism: meeting Algeria’s Ahmed Ben Bella in 1964, minutes record, he 'railed against the suggestion that "all blacks are good and all whites bad" and [stated that] "the wrongheaded idea of divisions according to race merits the strongest censure"' (Byrne 2015: 924). Naše teme, which published two special issues on Africa in 1961 and 1979, described its hopes for Africa's future in the 1960s and its explanations for those dashed hopes in the 1970s through the Marxist paradigm of exploitation, dependency, and neo-colonialism - a term theorised in 1961-5 by Tito's Non-Aligned ally Nkrumah (Young 2016: 46-9). With colonialism described as a 'Western European' imposition (ŠvobĐokić 1979: 802; emphasis added), racism as a sin of, above all, the white regimes in South Africa and Rhodesia (Vukadinović 1979: 539) and 'the Black question' as what punctured the myth of America (Lisinski 1964: 2005), Yugoslavia seemed outside any of these things. If Miglena Todorova (2006: 205) believes state socialist Bulgaria still constructed identity around 'whiteness and civilization', continuing to attach symbols of cultural difference and backwardness to African and Asian spaces and bodies, was this less likely with Yugoslavia because it did not have membership of the Soviet bloc to perform?

The evidence is not so plain. Yugoslav diplomatic texts like Leo Mates's 1970 book on non-aligned theory and practice could, Konstantin 
Kilibarda argues, display 'Eurocentric' tendencies: Mates, via Nehru's The Discovery of India and US developmental science, praised Indian anti-colonial movements' development of Non-Alignment and identified Yugoslavia more with 'Afro-Asian countries' than 'Europe', yet believed anti-colonial liberation movements had needed European revolutionary thought's 'platform and ... spirit' to mature and considered modernisation projects were still struggling with Africa's 'primitive social structures' (Kilibarda 2010: 39). ${ }^{12}$ Representations of travel mediated Yugoslav Communists' and writers' encounters with Africa to the public. Authors of 1960s travelogues often expressed shame or guilt at their whiteness, considered themselves better able to understand Africa than Westerners, or even, like Oskar Davičo, wrote of wanting to renounce their white skin (Radonjić 2015). The Serbian historical novelist Dobrica Ćosić, accompanying Tito's 1961 yacht-borne West Africa visit, wrote instead about uncomfortable encounters with climactic and sonic difference that left him feeling more white and European, while Tito and his hosts co-operated to stage spectacles of white-uniformed Tito receiving prestigious hospitality that resembled colonial photography (Hozić 2016; Vučetić 2016).

Encounters with racialised difference and blackness were, meanwhile, an unusual yet everyday part of life for inhabitants of university cities where thousands of students from Non-Aligned countries studied. As in the Soviet bloc (Matusevich (ed.) 2007; Carew 2015; Slobodian (ed.) 2015c), Yugoslavia educated these students as the future engineering, technical and medical cadres of their newly liberated countries' journey towards modernisation - where Yugoslavs (again as in the Soviet bloc) believed they had an important pedagogical role (Kilibarda 2010: 39). ${ }^{13}$ Though most returned, dozens founded interracial families, becoming a longer part of the region's still-largely-silenced history of people of colour. One, Peter Bossman from Ghana, became postsocialist Europe's first black mayor when elected in Piran in 2010 (Intihar 2013). Another was David Bangoura, father of the Croatian TV presenter Hamid, who recalled in 2007: 
I came to Zagreb aged 20, as one of 30 Guineans who were coming to study here. We were the first Africans who ever came to former Yugoslavia. Before that most of us studied in Paris, but when Guinea gained independence in 1958, the French sent us home. The first president of Guinea, Sékou Touré, was a friend of Tito, so after we came back from Paris they quickly sent us to Zagreb. When before Zagreb we landed in Belgrade, we were the first Africans the people there had seen live. They looked at us, they followed us in the street, and some even touched us to see whether our skin colour would rub off on their hands. They thought we were covered in paint. (Simić, Biluš and Pavić 2007)

Bangoura hints at the exoticism with which these Belgraders had learned to perceive African bodies and blackness in 1958, but also at how disconnected this region's black history has been. The Guineans were certainly among the very first African students welcomed in Yugoslavia, but, enslaved Africans' history in Ulcinj shows, certainly not the first Africans in the region - and yet that very history would have complicated socialist Yugoslavia's performances of postcoloniality.

Peter Wright's work on 'the ambivalence of socialist anti-racism' (Wright 2016) in Communist officials' responses to African students' complaints (about living conditions and racist abuse from Yugoslav students) indeed shows Yugoslavs displaying what studies of Western anti-racism call 'white fragility' (DiAngelo 2011): when public ideology and Yugoslav socialist identity were so committed to anti-colonialism and anti-racism, how could Yugoslavs be racist? Yet Africans experienced racism. A dynamic so characteristic of twentieth- and twenty-first-century Western anti-racism (Lentin 2004) also existed in socialist Yugoslavia, another commonality across the supposed East-West divide.

Other Non-Aligned migration routes suggest further ambiguities of the region's position in the global racialised order. Yugoslavs faced fewer visa requirements when travelling abroad than citizens of either superpower bloc, a freedom of travel that was always conditional on income and political standing but greatly exceeded the visa restrictions Western 
states would place on ex-Yugoslavs during the 1990s wars (Chapter 4). Guest-worker programmes relieved Yugoslavia's unemployment programmes until host states officially ceased them after the 1973 oil crisis (Shonick 2009). Approximately 600,000 workers (1.3 million people including dependants), most from economically disadvantaged agricultural regions like the Dalmatian hinterland, Herzegovina and Macedonia, became 'Gastarbeiters' (supposedly temporary labour migrants) in north-west European states filling labour shortages from the Northern and Southern Mediterranean (Daniel 2007: 280). ${ }^{14}$ The history of race in West Germany, which hosted the most Yugoslav guest-workers, therefore includes how authorities racialised Croats, Roma and other 'Yugoslavs' compared with the even larger Turkish and Kurdish guest-worker communities (Sieg 2002; Chin 2007; Clarkson 2008; Molnar 2014).

Yugoslav construction-workers and engineers, meanwhile, travelled to Yugoslavia's Afro-Asian trading partners to build factories, infrastructure and hotels. Historians of state socialism have recently begun investigating this form of internationalism, with Łukasz Stanek (on architects from state socialist countries in West Africa) and Vladimir Kulić (on Yugoslav architects' designing hotels and expo pavilions) both challenging the idea that architectural modernity only travelled Westto-East and North-to-South. Instead, Kulić (2014: 29) writes, these connections reveal 'alternative, more convoluted paths, which circumvented the hierarchical structures of colonialism or superpower hegemonies'. Black African, white anglophone and white state socialist European experts all competed over whose historical experiences created the best understanding of 'modernization' - with the Hungarian architect Charles Polónyi (designer of several important projects in Accra), Nkrumah and Tito himself all paralleling east European and West African experiences of colonisation (Stanek 2015: 435). ${ }^{15}$ With 'highly-skilled', 'white-collar' Yugoslav workers in developing countries in a better structural position than lower-skilled guest-workers in western Europe (Kilibarda 2010: 39), there was not one unified Yugoslav migrant-worker subjectivity: experiences of labour migration were structured by 
geography and class, as well as gender (Morokvasic 1991) and intraYugoslav dynamics of ethnicity and development.

Non-Aligned ideology even informed the racial politics of Yugoslav popular music (Chapter 1). Early 1950s Yugoslav Communists, like authorities in many European countries, expressed reservations about jazz, and some People's Youth reports about music considered 'vulgar ... black dances' and jazz music inappropriate for the youth supposedly being remade as new socialist men and women - but they were not as concerned, Dean Vuletić (2015: 29) argues, as similar moral guardians in the West (or the USSR), because Yugoslavia lacked any 'significant black minority, colonialist tradition, and stationed African-American soldiers', and because of Yugoslav foreign policy's anti-colonial stance. Instead, race was an unstable signifier, with embodied and sonic markers of racialised identity in original contexts liable to be detached and reassembled in translation. ${ }^{16}$ The 'sonic blackness' (Weheliye 2005: 5; see Brooks 2011) of Aretha Franklin's or Nina Simone's voices, like the qualities of French or Italian divas, became markers of virtuosity for female singers at the more urban(e), cosmopolitan pole of Yugoslav taste hierarchies.

Racialisation of Yugoslav Roma and black musicians from abroad meanwhile intertwined in unstable patterns of belonging and exoticism. One Belgrade showbusiness magazine, $R T V$ revija, reported in 1981 on the Boney M frontman Bobby Farrell's wedding to Jasmina Šaban, an eighteen-year-old Skopje-born Romani woman whose family were 'Yugo-gastarbeiters' in Vienna. ${ }^{17}$ Up to 20,000 people in Skopje watched the couple arrive for a ceremony where Farrell, the magazine wrote, 'became our son-in-law', on a level with 'the sensational ceremonial of Lady Diana and Prince Charles'. This adoption of Farrell into the national collective, simultaneously reiterating Yugoslavia's international standing, accompanied a sexualised, racialised gaze towards black female entertainers: '[e]verybody anticipated the arrival of the dark-skinned black women [tamnoputih crnkinja] from the group "Boney M". The attractive trio did not appear' (Aćimović 1981). Even if the Yugoslav national 'we' accommodated Roma (somewhat) better than either 1980s Bulgarian 
identity narratives or the ethnicised identity narratives that overthrew Yugoslav ones (see Sardelić 2016), and even if Non-Alignment facilitated closer identifications with Africanity than in the Soviet bloc, whiteness had not been displaced from identity construction in Yugoslavia. The 1980s breakdown of state socialist ideology would make it more prominent yet, especially but not only in the north-western republics.

\section{Race, whiteness and the breakdown of state socialist ideology after Tito}

After Tito died in 1980 and Yugoslavia's debt crisis intensified in 1982, programmes to reform Yugoslav socialism and constitutionalism which sought extensive internal and external geopolitical realignments emerged from Slovenia, then also Croatia. Their invocations of 'Europe' and modernity intensified intra-Yugoslav 'nesting orientalisms' (Bakić-Hayden 1995) and also - more rarely acknowledged - rearticulated the whiteness of the north-western, especially Slovenian, ethnonational identities (Longinović 2011). The Slovenian platform, acquiring the slogan 'Europe Now!' (Paternost 1992: 52), ${ }^{18}$ aimed to strengthen the Yugoslav republics against the federal centre and to align Slovenia with 'Europe' in general and the late-Cold-War imaginary of 'central Europe' in particular, within a reformed Yugoslavia or, as this programme clashed in 1989-90 with Milošević's authoritarian re-centralisation, outside. Within south-east European symbolic geographies, situating an ethnonational identity and its associated polity within central Europe detached it from 'the Balkans', the 'Orient', the Ottoman legacy, Islam and the civilisational hierarchies projected on to these by European racisms for centuries. The 'nesting orientalisms' that south-east European studies equipped itself through postcolonial thought to recognise in the early 1990s were also products of a deeper global raciality - even if the theory itself bracketed off race (Bjelić 2009, 2017; Kilibarda 2010).

Attachments to 'central Europe' (Boatcă 2006: 99) or discourses of 'return to Europe' (Imre 2005: 82) across late state socialist and 
postsocialist Europe were indeed, Manuela Boatcă and Anikó Imre argue, simultaneously attachments to whiteness. Tanja Petrović develops this further, arguing that anti-Communist narratives of national history in eastern Europe even racialised state socialism itself - by characterising Russia/the USSR as 'Asiatic', then socialism as a Russian-Soviet imposition (obscuring how far members of the nation had welcomed and, even in Soviet-dominated structures, adapted socialism). Consequently, eastern Europeans 'often treat[ed] socialism as something essentially nonEuropean that originated in Asia and was enforced upon them', making EU accession seem like 'returning home' (Petrović 2009: 62; emphasis original). In Yugoslav contexts the 'Asiatic' frame could also be employed against Serbia - and, in some anti-Milošević discourses by the Serbian youth movement Otpor before his fall in 2000, even within it (Kilibarda 2010: 45$).{ }^{19}$

'Returns to Europe' imagined by dissident intellectuals and the winners of Slovenia's and Croatia's multi-party elections might even have drawn on a transnational revival of 'Europe' in late 1980s state socialisms, from Hungarian aspirations to a bridging role in European security policy to Gorbachev's imagination of a 'common European home', at a time when elites might have been losing faith in the alternative global project of connecting the state socialist world and Global South (Mark 2015). Pragmatic-technocratic reformers, and strategists expressing fears of terrorism and Islamic fundamentalism, were both 'appropriating' this position in Yugoslavia by 1989 (Kilibarda 2010: 40). Late Yugoslav and post-Yugoslav 'nesting orientalisms' thus rejected more than just the Balkans: they also rejected the alternatives implied within the NonAligned ideal. Seen in postcolonial, 'worldist' terms that recognise 'the entwinement of ... contending structures, histories, memories, and political economies' in world politics (Agathangelou and Ling 2009: 1; emphasis original), the turn away from Yugoslavia's Non-Aligned identifications - as race-blind as they were - was a further narrowing of worlds.

The silencing of Non-Alignment in post-Yugoslav accounts of the past - whether a consequence of the ethnic-antagonisms frame 
crowding out other topics, or willed exclusion - is just as problematic as the forgetting of coexistence across ethnonational boundaries and the marginalisation of how reformable Yugoslav socialism, even in the early 1980s, still seemed to be (topics that the 'social inequalities' turn in late Yugoslav history recovers). The literary theorist Vedrana Veličković, working on postcommunism and postcolonialism, amplifies Rada Iveković's sadness at disappearing Yugoslav translations of key anti-colonial works and adds her own memory, fifty years since Lumumba's death: 'I remember I have dined many times in the Lumumba student hall named after him in the 1990s without knowing anything about this piece of black history in Belgrade' (Veličković 2012: 172-3; see Iveković 2006). ${ }^{20}$ A 1,400-word obituary of Guberina, published by the Croatian Academy of Sciences and Arts in 2005, positions him as a linguist conversant with Charles Bally, Noam Chomsky and Ferdinand de Saussure, and founder of the respected Phonetics Institute, but has no space for his postcolonial internationalism beyond an observation about respect for 'other peoples', appropriating it for Croatian linguistic nationalism:

All forms of national narrow-mindedness were foreign to Petar Guberina, especially the denigration of other peoples and the contestation of their rights, but at the same time, as a humanist, he demanded respect for the national rights of his own Croatian people, Croats' right to call their own language 'Croatian' and to nurture and develop it in the spirit of their own tradition and for their own needs. (Kovačec 2005)

Both the deliberate rejection of social alternatives in post-Yugoslav ethnonationalisms, and the consequent dominance of nationalism and ethnopolitical conflict as frames for research, have created a politics of knowledge production - inside, outside and across the permeable inside-outside of, the region - that pushes state socialism's geopolitical complexity towards or beyond the margins of public consciousness. Socialist Yugoslavia's geopolitical identity, so often called 'between East and West', could involve even more than balancing Europe's privileged West and Othered East; sometimes it pulled Yugoslavia southwards out 
of Europe altogether, into the post-Bandung configuration that for scholars like Mignolo (2011: 273) ignited the decolonial moment. But this was not the first ambiguous racial formation in the Yugoslav region: even before unification, multiple such formations already circulated through the region, creating contradictory points of identification. Their legacies of racialised thinking and representation were translated into identity-making politics that even predated state socialism, let alone the postsocialism in which they would be expressed through transnational politics of race and whiteness that persist into the present.

\section{Notes}

1 Todorova's essay on temporalities and the history of European nationalism does not return to this point - yet it has more transformative implications than she suggested.

2 With thanks to Dario Brentin.

3 Slovenian folklore contains another coastal abduction narrative where a black stranger kidnaps a woman, 'Lepa Vida' ('Pretty Vida'). The song, adapted in 1832 by the national poet France Prešeren, terms the abductor 'črn zamorec' ('the black "zamorec", meaning both 'man from overseas' and 'Negro', and a racial slur in modern Slovenian). Marjetka Golež Kaučić (2002: 165), referring obliquely to past criticisms of racism in 'Lepa Vida', argues that the song dates from when Arab/Moor slave-traders were capturing coastal dwellers and so 'negative attitudes towards the "zamorec" ... have nothing to do with racism' - yet a nineteenth- or twentieth-century listener would still hear contemporary as well as historic undertones in 'zamorec'. With thanks to Julija Sardelić.

4 Greek sailors had called Korčula 'Black Korčula' for its thick forests.

5 Though Woolf (2002: 177) argues that Fortis could not find 'a racial or physiognomic formula to sum up the national distinctiveness of the Morlacchi', few tropes were more common than 'the Hottentots' in producing European imaginations of race and sexuality (Gilman 1985).

6 Did this title symbolically cast satellites like East Germany as 'sons' of Soviet Russia?

7 Afghanistan, Burma, Cambodia, Ceylon, the People's Republic of China, Cyprus, Egypt, Ethiopia, the Gold Coast (soon to become Ghana), India, Indonesia, Iran, Iraq, Japan, Jordan, Laos, Lebanon, Liberia, Libya, Nepal, Pakistan, the Philippines, Saudi Arabia, Sudan, Syria, Thailand, Turkey, North Vietnam, South Vietnam and Yemen.

8 Attendees were Afghanistan, the Algerian National Liberation Front, Burma, Cambodia, Ceylon, Congo, Cuba, Cyprus, Ethiopia, Ghana, Guinea, India, Indonesia, Iraq, Lebanon, Mali, Morocco, Nepal, Saudi Arabia, Somalia, Sudan, 
Tunisia, the United Arab Republic, Yemen and Yugoslavia (Alden, Morphet and Vieira 2010: 50).

9 This uses 'white but not quite' differently from Anna Agathangelou (2004b: 88), who describes stigmatisation of sex-workers from postsocialist European countries, but both point to shifting racial identifications projected on to postsocialist Europe.

10 The Croatian philosopher Rada Iveković writes: 'in the early seventies, as a well known German feminist scholar had asked us [for] contributions for a collective book and proposed to bundle us up in the Eastern block section, we asked to be put into the part concerned with the Third World. This is where we saw ourselves then' (Iveković 2006).

11 Kiiru had made Lerman Dragutin in 1988, about the Karlovac explorer, and was first president of the Croatian-African Friendship Society, founded in 2004.

12 Contrast Basil Davidson's anti-primitivist explanation of African postcolonial social structures, informed by his knowledge of early socialist Yugoslavia (Davidson 1992). With thanks to Sunnie Rucker-Chang.

13 A 1982 report from the Federal Institution for International Co-Operation in Science, Cultural Development and Technology, Belgrade, stated that Yugoslavia 'did not approach this co-operation as "extension of assistance", nor from the position of superiority or level of development or expert-scientific supremacy, but on the contrary from the position of common interests' (Zimić 1982: 13) - suggesting that the author of the report might have been aware it could be perceived as less solidaristic. The positioning of Yugoslavia as 'one of the most developed among Non-Aligned [countries]' (Tito to Algerian television, 1973) indeed established a hierarchy of modernity that could easily be racialised (Kilibarda 2010: 39).

14 The Yugoslav feminist Mirjana Morokvasic, writing in 1991 on 'Fortress Europe and migrant women', argued both ' $[\mathrm{t}]$ he colonial past in some countries and economic supremacy in others' stigmatised 'migrant and minority women', including the Yugoslav and Vietnamese women workers of both Germanies who were sent home if they gave birth (Morokvasic 1991: 73-4).

15 These professions of internationalism 'contrasted uncomfortably' with evidence of everyday racism and anti-blackness in state socialist societies: while a Ghanaian journalist was writing that Bulgarians, with 'five hundred years ... under the Turkish rule ... understand the African and are very sympathetic with her struggle, African students in Sofia, Prague, Moscow and Beijing were mobilising against unequal conditions (Stanek 2015: 435; see Hessler 2006: 50).

16 The People's Youth of Yugoslavia (Narodna omladina Jugoslavije) was the $\mathrm{KPJ} / \mathrm{SKJ}$ youth organisation, and reported on young people's internalisation of state socialist ideology as part of its work.

17 Boney $M$ were an Afro-European band formed by a white German producer.

18 Emerging in 1989, this became the Slovenian opposition slogan in the 1990 elections. 
19 One Otpor document, which for Kilibarda illustrates 'cultural racism' in Europeanness and reform discourses, argued that Serbia and the Balkans contained two political tendencies. The first was European and individualistic. The other, in the document's words, was 'Asiatic, not after the continent from which it originally comes, but because of the mentality of the Ottoman sultanates and džamahirijau (sic.), which has its origins in the nearly five-centuries of Turkish occupation strongly reinforced with the ruling ideology of pseudosocialism in Serbia ... The attempt to preserve this model can only succeed temporarily in small societies forgotten by the world like Cuba - but is impossible at a crossroads in Europe's centre like Serbia' (Kilibarda 2010: 45).

20 The USSR, meanwhile, renamed its 'Peoples' Friendship University' in Moscow (which educated Asian, African and Latin American students, opened in 1960) after Lumumba (Matusevich 2012: 335). 